\title{
Immediate and delayed effects of a mass mortality event on gorgonian population dynamics and benthic community structure in the NW Mediterranean Sea
}

\author{
Cristina Linares ${ }^{1,2,3, *}$, Rafel Coma ${ }^{1}$, David Diaz ${ }^{2}$, Mikel Zabala ${ }^{3}$, Bernat Hereu ${ }^{3}$, \\ Lluís Dantart ${ }^{4}$ \\ ${ }^{1}$ Centre d'Estudis Avançats de Blanes, Accés Cala Sant Francesc 14, 17300 Blanes, Girona, Spain \\ ${ }^{2}$ Institut de Ciències del Mar, Passeig Marítim 37-49, 08003 Barcelona, Spain \\ ${ }^{3}$ Departament d'Ecologia, and ${ }^{4}$ Centre de Recursos de Biodiversitat Animal, Facultat de Biologia, Universitat de Barcelona, \\ Avda Diagonal 645, 08028 Barcelona, Spain
}

\begin{abstract}
In the boreal summer of 1999, many invertebrates of hard-bottom communities in the NW Mediterranean Sea suffered mass mortality. Our study assessed the population of the temperate octocoral Paramuricea clavata before the event and monitored the population over the following $4 \mathrm{yr}$. Spatial patterns showed decreasing mortality with increasing depth between 0 and $50 \mathrm{~m}$, as well as high local variability. The temporal pattern was characterized by a sharp decrease in biomass $(58 \%)$ shortly after the event caused by the combined effect of colony death ( $9 \%$ of the population) and an increase in the extent of colony injury (from $9 \%$ before the event to $52 \%$ shortly after it). After 4 yr of monitoring, our results indicated a large delayed effect of the event. Population density decreased continuously after November 1999, and by the completion of the study in November 2003 the accumulated density decrease was $48 \%$ of the initial population. This decrease was mainly due to the death of colonies subjected to extensive injury, and because recruitment did not offset mortality. After November 1999, biomass continued to decrease at a slow rate, becoming almost constant after November 2001. Overall, the delayed effect of the event accounted for a $70 \%$ loss in P. clavata biomass. The fact that a stabilization of the density and biomass of this species was observed during the last year of our study suggests that the delayed impact of the 1999 mass mortality event may be nearing its end. Nevertheless, given the low dynamics of $P$. clavata and its role as a habitat former, the delayed effect of the mass mortality event indicates the relevant role that disturbance can play on the population dynamics of this species and as a community structuring force on the coralligenous community.
\end{abstract}

KEY WORDS: Coralligenous community $\cdot$ Injury $\cdot$ NW Mediterranean Sea $\cdot$ Paramuricea clavata Partial mortality

\section{INTRODUCTION}

Diseases and mass mortalities of organisms have been increasingly reported in several marine ecosystems (e.g. Epstein et al. 1998, Harvell et al. 2002, 2004, Kim \& Harvell 2004, Ward et al. 2004). Most documented mass mortality events involve a decline in ecosystem engineer species (Jones et al. 1994) such as corals, sponges and gorgonians, whose structural complexity strongly contributes to the biodiversity of the ecosystem (e.g. Wendt et al. 1985, Sebens 1991). The effects of mass mortality on the conservation of biodiversity at the whole community level are a main concern (Hughes 1994, Aronson \& Precht 1997, Green- 
stein et al. 1998, Loya et al. 2001), rather than the survival of particular species which, being mostly clonal organisms, have a great capacity to recover from partial mortality (Hughes \& Cancino 1985, Hughes \& Jackson 1985).

Many of these ecosystem engineer species are also long-lived and show parsimonious life history traits. Among the most common of these traits are poor dispersive capacity by sexual reproduction, delayed maturity, low and infrequent settlement, and high post-settlement mortality (Hughes \& Cancino 1985, Jackson 1985, Garrabou \& Harmelin 2002, Coma et al. 2004). Because recruitment success is generally low, the recovery of these populations depends mainly on the capacity of colonies to recover from damage, the effects of which may persist for a long time after an event (Hoegh-Guldberg 1999, Wilkinson et al. 1999, Guzmán \& Cortés 2001). In spite of this potential for long lasting effects, most assessments of the impact of mass mortality events, especially of bleaching events, have been conducted immediately after the event or only over short observation periods (McClanahan et al. 2001, Baird \& Marshall 2002). These studies allow detection of the immediate impact of such events, but they do not assess the delayed impacts, which may be even more important for community health. Usually, major disturbances are studied because of their immediate impacts, but it is increasingly believed that the long-term effects of these events can also pose a significant risk to affected populations and ecosystems (Monson et al. 2000).

In contrast to information on tropical mass mortality events, data on the impact of these events in temperate ecosystems are poor. In the boreal summer of 1999 a mass mortality event affected many invertebrates of hard-bottom communities in the Ligurian Sea (NW Mediterranean) (Cerrano et al. 2000, Perez et al. 2000). Mass mortality events in these communities have been reported in several NW Mediterranean locations (Harmelin 1984, Rivoire 1991, Bavestrello et al. 1994, Mistri \& Ceccherelli 1996). However, the summer 1999 event differed greatly from other reports in many ways: in contrast to previous events, it affected (1) a wide variety of species and taxa, rather than a single species or taxon; and (2) communities at a regional scale (i.e. several hundreds of kilometers) as opposed to a local effect (i.e. tens of meters or kilometers).

Previous studies on the 1999 mass mortality were instrumental in recognizing the occurrence of the event and in providing an initial estimate of its impact (Cerrano et al. 2000, Perez et al. 2000, Garrabou et al. 2001). However, the delayed impact of the event has not been documented, because previous studies were conducted shortly after the event and did not account for the fate of partially injured colonies. A full evalua- tion of impact requires a temporal sequence of data acquired before the event that extends for a sufficient length of time after the event to provide data on a full sequence of recovery (Underwood 1994). The unpredictability of mass mortality events makes it very unlikely that researchers will have such data, but by chance we have survey data from before the mortality event of 1999 (see 'Materials and methods').

This study is the first to examine the multi-year effects of the 1999 mass mortality event on the gorgonian species Paramuricea clavata (Risso, 1826), by tracking a population from before the event to $4 \mathrm{yr}$ after the event. This paper aims to improve our understanding of the role of both immediate and delayed impacts of low frequency disturbance events, particularly on the structure and dynamics of gorgonian populations and on the coralligenous community in general. The coralligenous community (Ballesteros in press) is one of the most emblematic of the Mediterranean communities, and it is characterized by the low turnover of its main structural contributors (Coma et al. 1998a, Ribes et al. 1999, Garrabou et al. 2002).

\section{MATERIALS AND METHODS}

Study system. In late 1998, the Port-Cros National Park (NW Mediterranean, France) initiated a monitoring program of the effects of recreational diving on the coralligenous community. The long-living gorgonian Paramuricea clavata was selected as a good indicator of this community because it is one of the main contributors to community structure and biomass (True 1970). The population was first surveyed in June 1999. Mass mortality was first detected in the Port-Cros area in late summer 1999 (Perez et al. 2000). Owing to the magnitude of the event, we surveyed the gorgonian population again in November 1999. Thereafter, we performed annual surveys until 2003.

The marine part of the Port-Cros National Park covers 1300 ha and encompasses 2 small islands of the Hyères Archipelago (France) in the NW Mediterranean Sea (Fig. 1a,b). The distribution, bathymetric range and population structure of the Paramuricea clavata populations in the park were previously described by Harmelin \& Marinopoulos (1994). The species is unevenly distributed, with dense populations found at 4 locations: La Gabinière, Pointe du Vaisseau et la Croix, Montrémian and La Galère. The upper distributional limit in the park is $\sim 15 \mathrm{~m}$ depth, and P. clavata reaches the lower rocky foundations of the island at about $65 \mathrm{~m}$, where rocks are replaced by the sandy bottoms that surround the park (Harmelin \& Marinopoulos 1994).

Depth survey. The effect of depth on the occurrence of the mass mortality event was examined in Novem- 

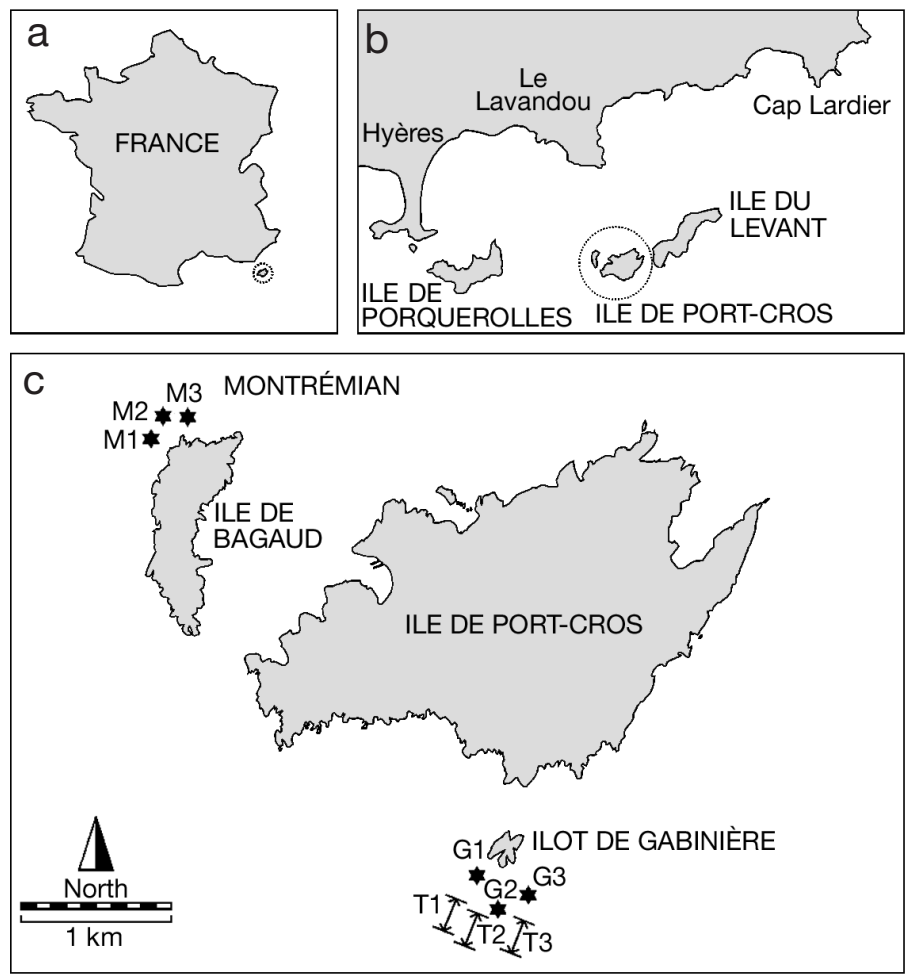

Fig. 1. Paramuricea clavata. $(\mathrm{a}, \mathrm{b})$ Distribution of the shallow population at Port-Cros National Park (NW Mediterranean, France) and location of sampling sites; (c) permanent plots at Montrémian (M1, M2, M3), La Gabinière (G1, G2, G3) and depth transects (T1, T2, T3)

ber 1999 at the deepest population (La Gabinière) along 3 randomly selected transects. Each transect consisted of laying a line along the slope of the reef between 0 and $50 \mathrm{~m}$ depth. Total height and the extent of injury of all the colonies within a $0.5 \mathrm{~m}$ width on both sides of the line were measured ( $N=284$ colonies). The extent of injury was estimated as the proportion of each colony's total surface that showed no tissue (i.e. denuded axis) or overgrowth by other organisms (as in Nagelkerken et al. 1997, Harmelin et al. 1999).

Permanent surveys. Because of the patchy distribution of Paramuricea clavata (Harmelin \& Marinopoulos 1994) and the high local variability of the impact of the event (Perez et al. 2000, Garrabou et al. 2001), we used permanent plots to examine and monitor the population, and also to study the processes and mechanisms that determine the fate of damaged populations.

In June 1999, 3 permanent plots were set up at 2 locations: La Gabinière and Montrémian (Fig. 1c). The plots were randomly selected within the same depth (approximately $25 \mathrm{~m}$ ) and orientation (facing north) to reduce variance in population structure and density. Each plot was $4 \mathrm{~m}$ long and $0.8 \mathrm{~m}$ wide $\left(3.2 \mathrm{~m}^{2}\right.$ in surface). To facilitate mapping accuracy, each plot was partitioned in $40 \times 40 \mathrm{~cm}$ quadrats. The corners of each plot, as well as those of each quadrat, were marked with either steel climbing parabolts or PVC screws fixed to holes in rocky substratum with a 2-component putty. In each survey, elastic bands were placed around the corners to facilitate the recognition of quadrat borders. Each plot was monitored 6 times. The first survey was performed in June 1999 (before the mass mortality event), the second shortly after the event (November 1999), and the remainder in June 2000, November 2001, November 2002 and November 2003.

During the first survey, all gorgonian colonies in each $40 \times 40 \mathrm{~cm}$ quadrat were mapped on a polyvinyl sheet by SCUBA divers. On subsequent dates, maps from former surveys were used to facilitate the reidentification of each colony. For each gorgonian, colony height, extent of colony injury and nature of epibionts were recorded. Colony height was measured with a ruler as the distance between the colony base and the end of the farthest tip. The extent of colony injury was estimated as described above. The colonies at the depth of the permanent plots $(\sim 25 \mathrm{~m})$ developed mainly on a single plane, which facilitated the estimate of extent of injury. Epibionts were identified at the level of large taxonomic groups, and the abundance of the most frequent taxa was recorded.

A number was assigned to each colony for purposes of recognition for the database and for use in following surveys. This procedure allowed us to monitor $>100$ colonies within each of the 6 permanent plots in the 6 surveys. Colonies were grouped for demographic analysis in size classes in accordance with their height; 6 classes were distinguished, each covering a range of $10 \mathrm{~cm}$ in height: $0-10,>10-20,>20-30,>30-40$, $>40-50$, and $>50 \mathrm{~cm}$.

In November 1999, we investigated whether the partial colony mortality differed among the distinct parts of the colony. For each of 115 randomly selected damaged colonies, the following information was recorded: colony height, extent of injury, type of injury and position of the injury within the colony (i.e. basal, central, apical, basal + central, basal + apical, central + apical, basal + central + apical). A $\chi^{2}$ test was used to examine differences in the position of the injury within the colonies.

To address the inherent limitations of permanent plots (e.g. that the results are representative of what occurs within the plot, but may not be representative of what occurs over the whole population patch), we examined whether the results obtained within these differed from those of random plots within the same 
population patch. For this purpose, we used 1 of the 2 study locations (Montrémian, $25 \mathrm{~m}$ depth). At this location, the species exhibit 3 dense population patches of about $60 \mathrm{~m}^{2}$ on separated rocky bars between 20 and $30 \mathrm{~m}$ depth. The comparison was performed on 1 of the 3 population patches. The extent of colony injury (partial colony mortality) from 9 pairs of quadrats randomly selected $\left(0.32 \mathrm{~m}^{2}\right.$ each pair) within a permanent plot was compared with that of 9 pairs of quadrats randomly selected from the same population patch. We used ANOVA, with Treatment and Quadrat as the independent variables (Quadrat nested in Treatment) and Partial mortality as the dependent variable.

Analysis. The periodical surveys of the permanent plots allowed the monitoring of 4 parameters of the population at Port-Cros: total mortality, partial mortality, contribution of each of type of injury to total injury, and colony size (height). Biomass monitoring over time came from data on colony size and on the extent of injury.

Total mortality was estimated as the death of colonies within each plot over time. Dead colonies included those with $100 \%$ surface injury and colonies that disappeared between surveys. To examine the effect of size on total mortality, the population was pooled into 6 size classes as described above. The population structure before the mass mortality event (June 1999) was compared with that of the colonies that died over the study period (June 1999 to November 2003). A $\chi^{2}$ test was used to examine differences in total mortality among size classes. Partial mortality was estimated as the percentage of tissue loss (coenenchyme) of each colony, including both affected and unaffected colonies, and is described as the extent of injury (i.e. the proportion of the surface of each colony that showed no tissue, or overgrowth by other organisms). Several observers were asked to estimate the injury levels of 100 colonies that exhibited from 0 to $100 \%$ of colony surface injury. Before the study started, we analyzed differences in observer estimates of the extent of injury, but no significant differences were apparent (1-way ANOVA $F_{2,297}=$ $0.172, \mathrm{p}=0.841$ ).

Differences in the extent of colony injury between the 2 locations (La Gabinière and Montrémian) were examined using a 2-way ANOVA, with Location and Plot (3 plots per location) as independent variables (Plot nested in Location). To quantify the effects of size and extent of injury on total mortality rate, we distinguished between 2 size classes (colonies $<10 \mathrm{~cm}$ in height and colonies $>10 \mathrm{~cm}$ in height) and 4 injury categories within each size class (unaffected colonies, colonies with less than $33 \%$ surface injury $[<33 \%]$, colonies with between 33 and $66 \%$ [ $33<$ surface injury $<66 \%]$, and colonies with more than $66 \%$ surface injury [>66\%]). The 4 surveys performed after the event (November 1999) provided 4 estimates of mortality rate as a function of size and extent of injury. The effect of size and extent of injury on mortality rate was examined by means of a 2-way repeated measures ANOVA, with Size and Injury extent as independent variables and the 4 time intervals as repeated estimates of mortality rate.

Recruitment was assessed as the number of new colonies that appeared in the permanent plots after each survey. Data on recruitment are essential as they contribute to our understanding of the population changes that occurred over the study period. However, the proper evaluation of recruitment rate of a longlived species such as Paramuricea clavata should be conducted within a long-term spatio-temporal evaluation of the parameter. Therefore, recruitment data are not analyzed in detail here.

The contribution of each type of injury (naked axis or epibiont taxa) to the total injury was estimated by examining the frequency and the rank of abundance of each type of injury. An index of abundance (IA) for each type of injury was calculated by weighting the frequency of each item with its abundance rank:

$$
\mathrm{IA}=\sum_{i=1}^{3}(4-i) f_{i}
$$

where $i$ is the ordinal rank (between 1 and 3) of abundance of each item among the epibiont taxa and naked axis of each injured colony, and $f_{i}$ is the proportion of injured colonies (frequency of cases) in which this item was at rank $i$.

Size (height in $\mathrm{cm}$ ) was measured for all colonies within the plots at each survey. Size was used to estimate biomass using a relationship reported in a previous study $\left(\mathrm{B}=0.002 \mathrm{H}^{2.61}\right.$; Coma et al. 1998b), where $\mathrm{B}$ is biomass of dry mass (DM) in $\mathrm{g}$ and $\mathrm{H}$ is colony height in $\mathrm{cm}$. Corrections for biomass loss caused by injury were introduced to calculations by subtracting the percentage of biomass equivalent to the percentage of colony surface affected by injury.

\section{RESULTS}

\section{Effect of depth on the mass mortality event}

The extent of colony injury with depth showed a similar pattern of decrease in all 3 transects examined. A depth threshold was observed around 30 to $35 \mathrm{~m}$ (Fig. 2): gorgonian colonies were severely affected above this threshold $(<30$ to $35 \mathrm{~m})$, whereas those below it were only a little affected ( 35 to $40 \mathrm{~m}$ ) or were unaffected (>40 m, Fig. 2). 


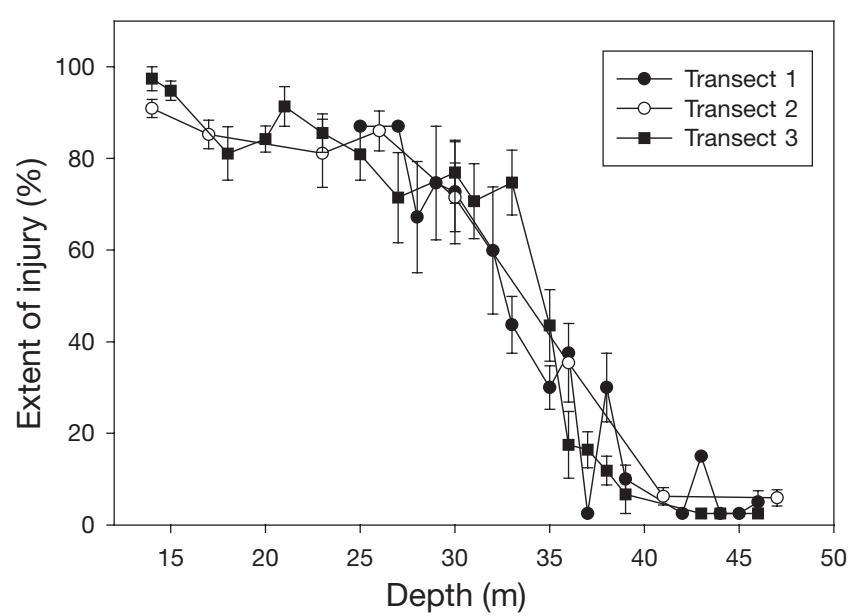

Fig. 2. Paramuricea clavata. Effect of depth on partial mortality (extent of injury, mean \pm SE) of affected and unaffected colonies along 3 depths transects at La Gabinière

\section{Density, survival and recruitment}

A total of 736 colonies were recorded at the beginning of the study at the 6 permanent plots, i.e. $38 \pm$ 11 colonies $\mathrm{m}^{-2}$ (mean $\pm \mathrm{SD}$ ). The density of colonies differed among plots. Those at La Gabinière showed the lowest and highest densities ( 25 to 59 colonies $\mathrm{m}^{-2}$ ), whereas those at Montrémian were closer to the average density (33 to 38 colonies $\mathrm{m}^{-2}$ ). Nevertheless, all the plots showed the same pattern of decrease in density over time after the event (Fig. 3). Shortly after the mass mortality event, $9 \%$ of the colonies died, exhibiting $100 \%$ surface injury. The rate of whole colony mortality decreased from about $2.9 \pm 0.4 \% \mathrm{mo}^{-1}$ $($ mean \pm SE) from November 1999 to June 2000, to about $1.0 \pm 0.2 \% \mathrm{mo}^{-1}$ from November 2002 to November 2003. By November 2003, the cumulative mortality of initial colonies amounted to a total of 358 dead colonies, representing $48 \pm 7 \%$ (mean $\pm \mathrm{SD}$ ) of the population (Fig. 3).

Patterns of density observed over the study period resulted from the integration of 2 processes: (1) colony death (i.e. colony mortality) and (2) the recruitment of new colonies. Recruitment over the 4 yr accounted for a total of 116 colonies, and was subjected to a mean annual mortality rate of about $45 \%$. Recruitment did not counterbalance mortality, and therefore the population density decrease was largely driven by the pattern of colony mortality (Fig. 3).

By comparing the size distribution of colonies at the beginning of the study (June 1999) with that of colonies that died over the study period (June 1999 to November 2003), we observed that all size classes exhibited similar proportions of dead colonies $\left(\chi^{2}=\right.$

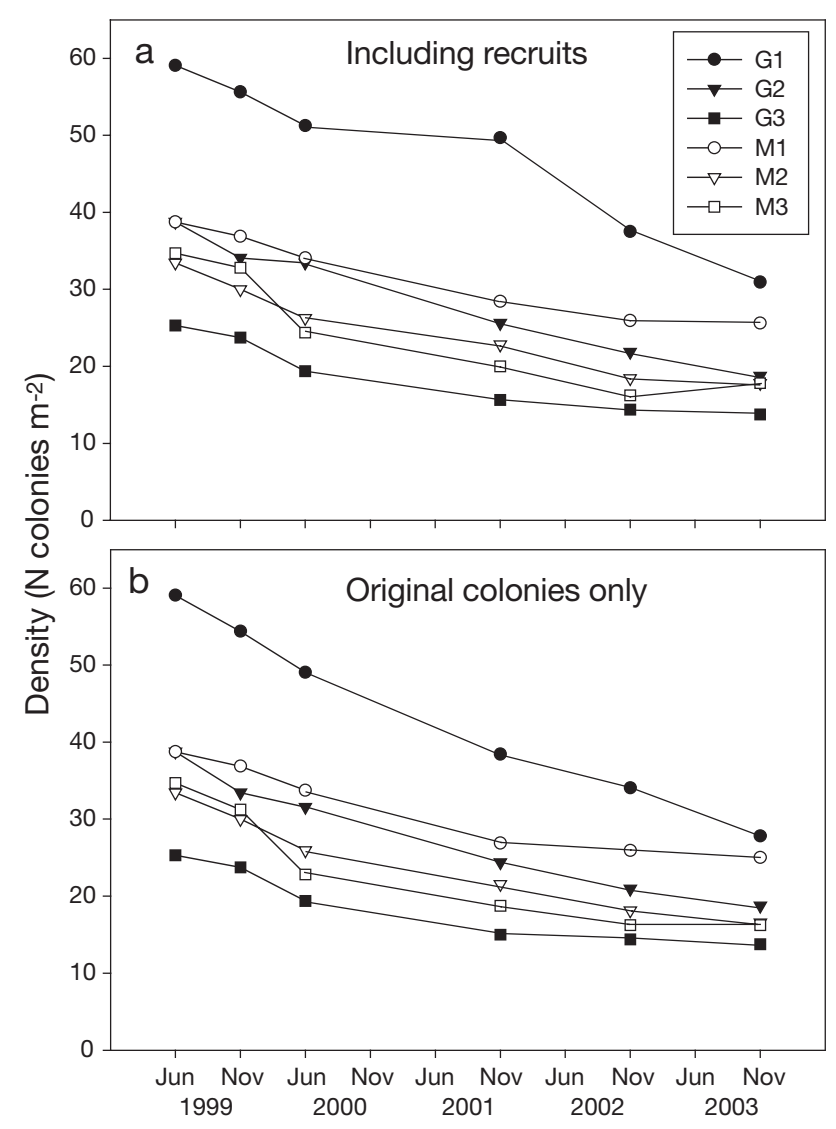

Fig. 3. Paramuricea clavata. Changes of density (N colonies $\mathrm{m}^{-2}$ ) at 6 permanent plots from June 1999 to November 2003: (a) density includes new born recruits; (b) only those colonies present at the beginning of the study were considered. Abbreviations for the permanent plots as in Fig. 1

5.449; df $=5 ; \mathrm{p}=0.358$, Fig. 4), and thus the overall mortality rate did not differ among size classes.

\section{Partial mortality}

In June 1999, partial mortality affected $28.4 \pm 6.0 \%$ (mean $\pm \mathrm{SD}$ ) of the colonies. Shortly after the event, this value increased to $76.1 \pm 8.4 \%$. Furthermore, the average extent of colony injury, which in June 1999 was about $9.2 \pm 2.3 \%$ of the colony surface, sharply increased to about $52.2 \pm 13.1 \%$ of the colony surface after the event at both locations (Fig. 5a).

The proportion of colonies exhibiting denuded parts (naked category, Fig. 6) was low before the event (2.5\% of the colonies in June 1999). The death of the coenenchyme left a large proportion of the axis of the colonies denuded shortly after the event (see Cerrano et al. 2000 for a description of the process, and Perez et al. 2000 for documentation at the study site), and allowed an extraordinary increase in injury and 


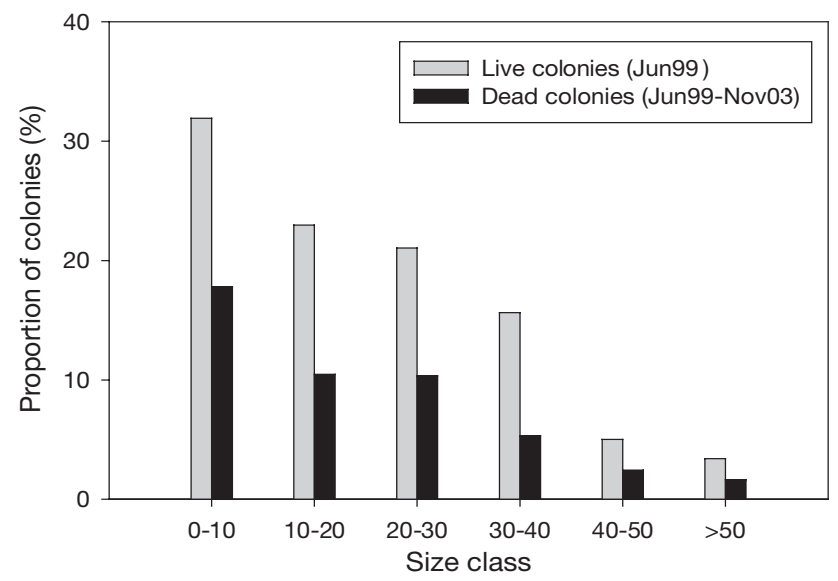

Fig. 4. Paramuricea clavata. Size structure of live colonies in June 1999 and of those that died over the study period (June 1999 to November 2003). Data pooled from all plots (total live colonies: 736 , total dead colonies: 358 )

epibionts with respect to June 1999 (Fig. 6). The proportion of colonies exhibiting denuded parts increased to $35 \%$ in November 1999; however, this proportion decreased after November 1999 because a large proportion of the denuded axis was progressively covered by epibionts (5.5\% in June 2000). Hydrozoans, bryozoans, polychaetes and algae were the main epibionts (Fig. 6).

In November 1999, injury affected all parts of the colony (i.e. basal, central and apical parts) with equal probability $\left(\chi^{2}=7.074 ; \mathrm{df}=5 ; \mathrm{p}=0.215\right.$, Fig. 7$)$ and the extent of injury did not differ among locations (2-way ANOVA, $F_{1,4}=0.126, \mathrm{p}<0.7407$, Fig. 5a).

The extent of injury varied significantly with colony size (Table 1a), although it did not vary among the largest size classes (Table 1b). The average extent of injury of colonies $>10 \mathrm{~cm}$ was more than 2 -fold that of colonies $<10 \mathrm{~cm}(61.25 \pm 1.45 \%$ vs. $24.14 \pm 2.50 \%$ [mean $\pm \mathrm{SD}$ ] of colony surface, Table $1 \mathrm{~b}$ ).

Table 1. Paramuricea clavata. (a) 1-way ANOVA comparing extent of injury $(\%$, arctan transformed) among size classes. Probability values < 0.05 were considered significant; df: degrees of freedom; MS: mean square; (b) Scheffé's contrast test: extent of injury are arctan transformed values

\begin{tabular}{|lccccc|}
\hline Source & df & MS & & $F$ & $p$ \\
\hline (a) & & & & & \\
Size classes & 3 & 0.062 & & 114.890 & $<0.001$ \\
Error & 722 & 0.062 & & & \\
(b) & & & & & \\
Extent of injury & & 0.239 & 0.586 & 0.624 & 0.616 \\
Source & $(1)$ & $(1)$ & $(2)$ & $(3)$ & $(4)$ \\
$0-10 \mathrm{~cm}$ & $(2)$ & $<0.001$ & & & \\
$10-20 \mathrm{~cm}$ & $(3)$ & $<0.001$ & 0.615 & & \\
$20-30 \mathrm{~cm}$ & $(4)$ & $<0.001$ & 0.743 & 0.994 & \\
$>0 \mathrm{~cm}$ & & & & & \\
\hline
\end{tabular}
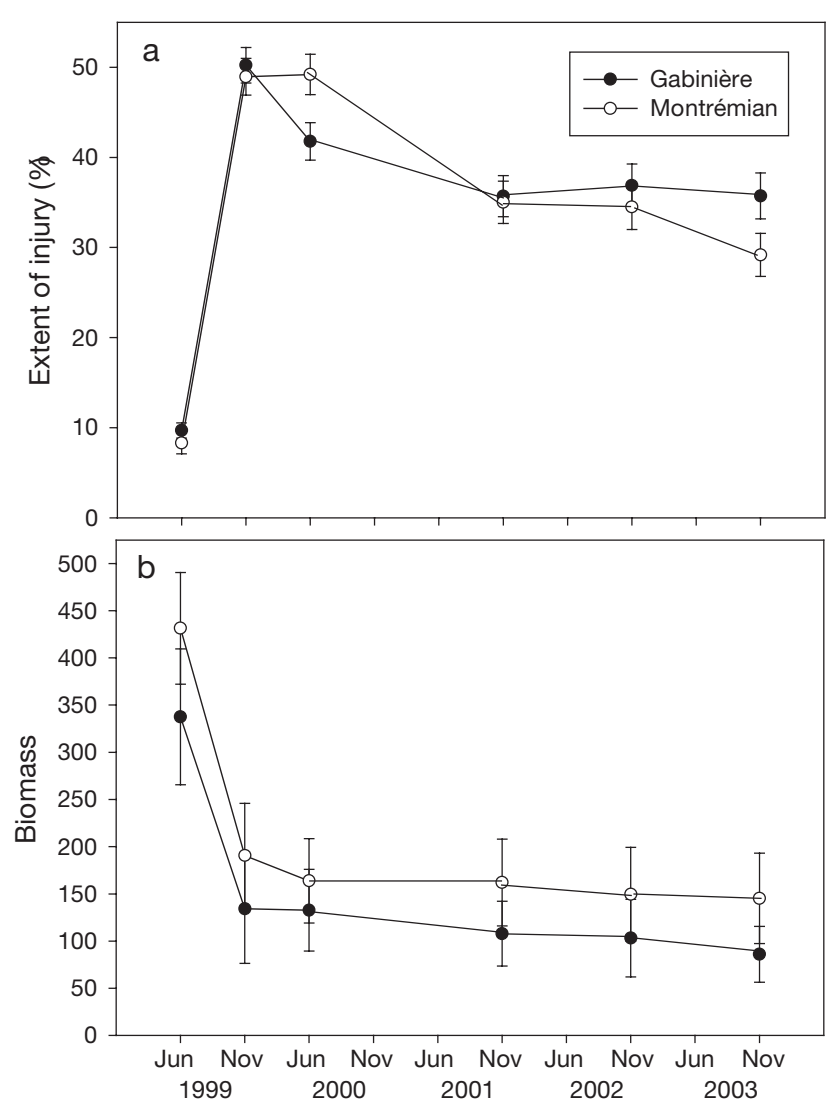

Fig. 5. Paramuricea clavata. Changes in: (a) partial mortality (\% of injured colony surface) including affected and unaffected colonies; (b) biomass $\left(\mathrm{g} \mathrm{DM} \mathrm{m}^{-2}\right.$ ) over the study period (June 1999 to November 2003) at 2 locations (Montrémian and La Gabinière). Data are mean $\pm \mathrm{SE}$

Although the overall extent of injury remained high ( $37 \%$ ) from November 2001 to November 2002, the proportion of colonies with denuded axis was similar to values observed before the event $(2.5$ and $2.8 \%$, respectively). In November 2003, the proportion of denuded axes approximately doubled $(6.0 \%$ of the colonies). Nevertheless, the overall extent of injury exhibited a slow but steady decrease from November 1999 to November 2003 (Fig. 5a).

In November 2003, we examined whether estimates of extent of injury on the permanent plots were representative of the study area by comparing these results with those obtained from the examination of randomly selected quadrats outside the plots. No significant difference in the average extent of colony injury between the 2 treatments was observed (permanent vs. random, 2-way ANOVA, $\left.F_{1,1}=100.907, \mathrm{p}=0.063\right)$; however, we found high small-scale variability of the effects of the event.

At all levels of injury, the total mortality of colonies $<10 \mathrm{~cm}$ in height was about $54 \%$ higher than that of larger ones $(>10 \mathrm{~cm}$ in height; 2 -way repeated mea- 


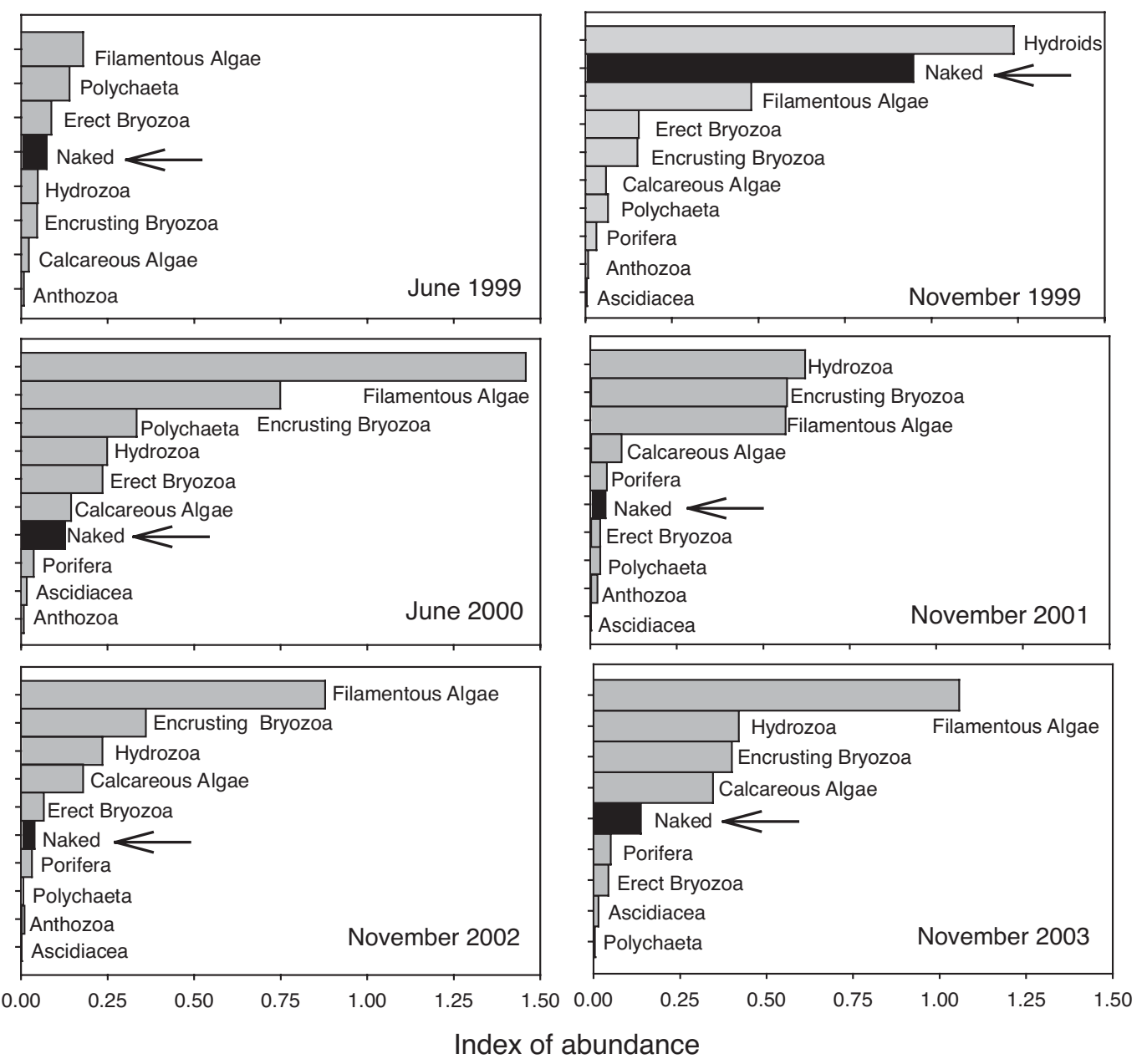

Fig. 6. Paramuricea clavata. Changes in the abundance index values of naked axes and in groups of epibionts over time

sures ANOVA, $F_{1,3}=12.285, \mathrm{p}=0.039$, size effect, Fig. 8). Furthermore, the extent of injury increased total mortality in both size groups (2-way repeated

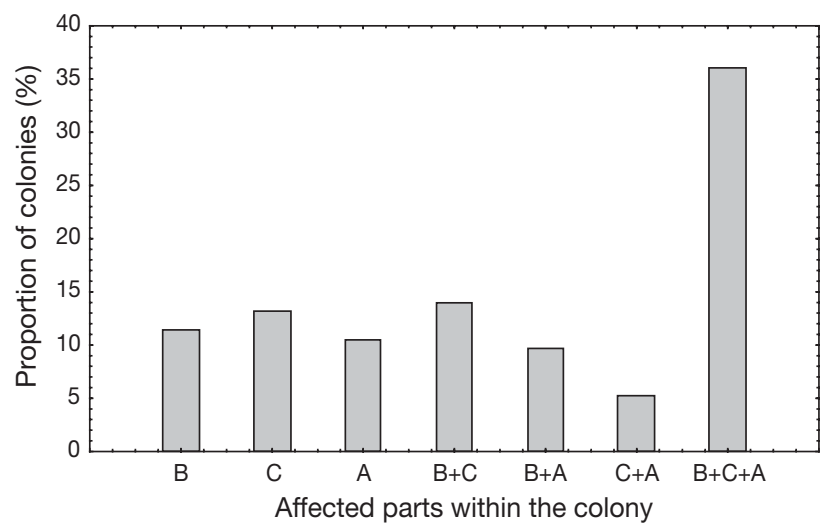

Fig. 7. Paramuricea clavata. Proportion (\%) of affected colonies exhibiting injury in each of the positions within the colony (basal: B; central: $C_{i}$ apical: A). Colonies with 100\% surface injury were not considered measures ANOVA, $F_{3,9}=4.159, \mathrm{p}=0.042$, injury effect) because the mortality rate of colonies affected by high levels of injury (i.e. $>66 \%$ of the colony surface) increased by about $80 \%$ for both (Fig. 8). The interaction between size and injury was not significant.

\section{Biomass}

At the beginning of the study, the mean biomass of Paramuricea clavata was $431 \pm 102 \mathrm{~g} \mathrm{DM} \mathrm{m}^{-2}$ (mean \pm $\mathrm{SD})$ at Montrémian and $338 \pm 125 \mathrm{~g} \mathrm{DM} \mathrm{m}^{-2}$ at La Gabinière (Fig. 5b). Shortly after the event, biomass at the 2 locations decreased by $58 \pm 3 \%$ of the June 1999 values. The pattern of decrease was similar at both locations (Fig. 5b). After November 1999, biomass values kept decreasing, but at a slower rate. After November 2001, the mean biomass values remained approximately constant. In November 2003, the average cumulative drop in biomass at the 2 locations accounted for $70 \pm 6 \%$ of the initial population (Fig. $5 \mathrm{~b}$ ). 


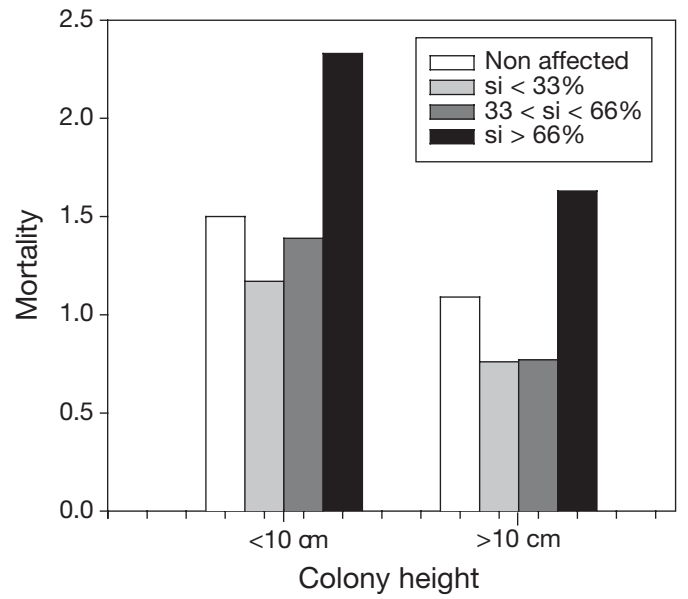

Fig. 8. Paramuricea clavata. Mortality rate (\% dead colonies $\mathrm{mo}^{-1}$ ) for colonies $<10 \mathrm{~cm}$ in height and colonies $>10 \mathrm{~cm}$ subjected to different proportions of injury of the colony surface from November 1999 to November 2003; si: surface injury

\section{DISCUSSION}

The population of Paramuricea clavata at Port-Cros National Park was strongly affected by the mass mortality event of the summer of 1999, which was first reported at the beginning of September (Perez et al. 2000). Because of logistical reasons, our first survey after the event was not possible until November 1999. This delay prevented us from observing the progressive death of the coenenchyme and its detachment from the skeletal axis (see Cerrano et al. 2000 for a description). However, the increase in extent of injury and the observation of denuded skeletal axes without macroscopic fouling in November 1999 (Fig. 6) is consistent with the relatively rapid occurrence of the event (in some cases it took a few days for healthy populations to show marked evidences of mortality) (Perez et al. 2000).

Previous studies on the 1999 mass mortality highlighted the occurrence of an unusual mortality for several species from the coralligenous community (Cerrano et al. 2000, Perez et al. 2000, Garrabou et al. 2001). These studies combined to determine (1) the geographic extent of the event and (2) the high diversity of taxa affected and, although data gathered before the event were not available, (3) provide a first estimate of the impact on the population shortly after the event. The availability of data obtained before the event has allowed us to provide a quantitative estimate of the immediate impact of the event to compare against the status of the population before its occurrence. Furthermore, the 4 yr monitoring after the event has allowed us to determine the delayed mid-term effects of the event on diverse parameters of the population.
In June 1999, the proportion of colonies with some amount of injury (28\%) was similar to that previously reported for the Paramuricea clavata population at Port-Cros (33\%; Harmelin \& Marinopoulos 1994) and at Medes Islands (32\%; Coma et al. 2004). Furthermore, the average proportion of colony surface affected by injury $(\sim 9 \pm 2 \%)$ was also similar to the value documented at Medes Islands $(8.6 \%)$ on the basis of a 6 yr monitoring survey (Coma et al. 2004). These results indicate that both the proportion of colonies with partial mortality and the extent of colony injury remain constant over time when not subjected to extraordinary events.

Despite the impact of the mass mortality event being highly variable among sites (proportion of affected gorgonians ranged from 60 to $100 \%$ of the population [Cerrano et al. 2000] and up to $90 \%$ of the population in distinct localities [Perez et al. 2000]), the increases in (1) the number of colonies exhibiting partial mortality (from 28 to $76 \%$ ) and (2) the average percentage of extent of injury (from 9 to $~ 52 \%$ ) from June to November 1999 is consistent with the general values provided by previous reports. The estimates of colony injury prior to the event provided a reference to quantify the impact of the 1999 event on the species. The mass mortality event at Port-Cros increased the number of colonies affected by partial mortality about 3 -fold and the average extent of injury about 6 -fold.

The death of the coenenchyme did not show a specific pattern; all parts of the colony from the base to the tips were similarly affected. This result is consistent with preliminary observations of Paramuricea clavata (Cerrano et al. 2000) and also of Corallium rubrum (Garrabou et al. 2001). However, P. clavata colonies $>10 \mathrm{~cm}$ exhibited a greater extent of injury than those $<10 \mathrm{~cm}$. It is unclear why the former were more affected. The accumulation of commensals, parasites and borers in large colonies may make them more susceptible to partial mortality. A higher percentage of partial mortality in large colonies in contrast to small ones has also been documented in several coral species (Meesters et al. 1996, Lewis 1997).

The amount and composition of epibionts showed considerable variation over time. A succession of different types of epibionts was observed, from abundant naked tissue and pioneering species such as hydrozoans, to older colonies of bryozoans, sponges and polychaeta. In spite of the increase and the variation of epibiosis after the mortality, epibionts covered the naked axes, but did not increase partial mortality of injured colonies as shown by the pattern of the injured surface over time. Denuded parts in unaffected populations always represented a small proportion of partial mortality (usually <5\%) (Harmelin \& Marinopoulos 1994, Coma et al. 2004) because, as shown by the 
results, they are quickly overgrown by a succession of epibionts. The extent and type of injury and growth of epibionts can be considered as an indicator of whether a disturbance event has occurred recently or not.

The mortality rate of small colonies is much higher than that of large colonies when the population is not subjected to extraordinary events (Coma et al. 2001, 2004). Therefore, the fact that the overall mortality rate did not differ among size classes (Fig. 4) indicates that the impact of the event on colonies $>10 \mathrm{~cm}$ in height was higher than that on colonies $<10 \mathrm{~cm}$. This was due to the 2-fold higher extent of injury of colonies $>10 \mathrm{~cm}$ in contrast to colonies $<10 \mathrm{~cm}$, and to the increase in mortality rate with increase in injury level.

The immediate impact of the mass mortality event on the population indicated a high impact in terms of increase in the extent of colony injury, but showed a much smaller impact in terms of total colony mortality ( 5 to $14 \%$; on average $9 \%$ of the population). These values are consistent with previous reports (10 to $18 \%$ of the population; Cerrano et al. 2000) and are highly relevant for Paramuricea clavata because natural mortality of this species, when not subjected to extraordinary events, has been estimated in the order of $3 \%$ of the population $\mathrm{yr}^{-1}$ for colonies $>10 \mathrm{~cm}$ (Coma et al. 2004). However, after $4 \mathrm{yr}$, total colony mortality amounted to almost half of the initial population. This appears to be due to a delayed stress response in the surviving colonies affected by extensive injury ( $>66 \%$ of the colony surface), because these exhibited a higher mortality rate than uninjured or less injured ones.

The large increase (several-fold) in mortality, shown by the contrast between the short-term versus the multi-year assessment of the event at the study site, indicates a much greater impact on Paramuricea clavata than that indicated by previous estimates (Cerrano et al. 2000). Low natural mortality rates of large colonies, in contrast to the high natural mortality rates of small colonies (Coma et al. 2001, 2004), play a critical role in attenuating the effects of long episodes of low recruitment; therefore, the long-term impacts of the high mortality rate of shallow populations of large colonies observed during this study are of concern. Modelling is required to address this issue. Population viability analysis (Morris \& Doak 2002) can be conducted by simulating scenarios with distinct frequencies of catastrophic events. In this framework, our estimates of mortality and recruitment rates, both during and after mortality events, together with previous data on mortality, recruitment, growth, density and size structure in non-catastrophic conditions may contribute to the development of these models.

Monitoring over the $4 \mathrm{yr}$ following the event has also shown that recruitment does not compensate for the losses caused by colony death (a total of 116 recruits subjected to a high mortality rate, in contrast to the 358 colonies that died). Furthermore, a decrease in the extent of colony injury was more apparent during the first $2 \mathrm{yr}$, diminishing thereafter. The observation that population biomass did not increase during the $4 \mathrm{yr}$ after the event, despite the decrease in extent of injury, indicates the breakage of the injured skeletal axis. This kind of breakage has been reported to be a healing mechanism in other Mediterranean gorgonians (i.e. Eunicella cavolonii, Bavestrello \& Boero 1986). The stabilization of density and biomass during the last year indicates that the delayed impact of the 1999 mass mortality event may be nearing its end, and that from here on the population may start to recover. However, recovery (interpreted here as the restoration of the population to a state comparable to that before the disturbance; Pearson 1981) is still far from being attained.

Several hypotheses have been proposed and discussed on the causes of the 1999 mass mortality event, including the presence of pathogens, chronic contamination (pollution), high temperature, and energetic constraints (Cerrano et al. 2000, Perez et al. 2000, Romano et al. 2000, Garrabou et al. 2001, Martin et al. 2002, Coma \& Ribes 2003). Biological surveys done after the event indicate that the most probable cause is climatic. The persistence of water column stability and high temperatures were the most distinctive climatic anomalies during this time period, and were caused by the absence of NW winds (Romano et al. 2000).

The spatial distribution of the mass mortality event is complex at both large and small spatial scales (Perez et al. 2000, Garrabou et al. 2001, this study). However, the impact on the population exhibited a marked depth pattern in which the shallowest colonies were the most affected. The threshold between affected and unaffected populations (in our study between 35 and $40 \mathrm{~m}$ ) was similar to that reported in eastern Ligurian Sea locations (i.e. $40 \mathrm{~m}$; Cerrano et al. 2000), but the event affected deeper populations at several other locations along the SE coast of France ( $45 \mathrm{~m}$; Perez et al. 2000). The mortality event at Port-Cros approximately coincided with the deepest thermocline that occurred at the end of summer 1999 (Harmelin 2004). This pattern supports the climatic hypothesis because of its relation with the thermal stratification present during that time period (Romano et al. 2000, Harmelin 2004).

In this regard, the recent warming of the Mediterranean (Pascual et al. 1995, Bethoux et al. 1998) has been related to the 1999 summer event (Cerrano et al. 2000, Coma et al. 2000, Perez et al. 2000, Garrabou et al. 2001, Coma \& Ribes 2003). In summer 2003, another mass mortality episode was observed across the NW Mediterranean coasts (Coma et al. 2003, J. M. Culioli pers. comm., J. Garrabou pers. comm.). Its occurrence 
indicates that the frequency of these events may be increasing as a result of global climate change. Therefore, a repetition of mass mortality events would be expected.

In the present study, Paramuricea clavata was used as an indicator species, representative of the complex benthic communities along the circalittoral rocky bottoms of Mediterranean coasts. However, given the structural and biomass contribution of the species (True 1970) to one of the most diverse Mediterranean communities (more than 1600 species have been listed in the coralligenous communities, Ballesteros in press), the survival of the community may be closely linked to that of the habitat-forming species. The absence or scarcity of this highly interactive species can leave a functional void that can cause linked changes to degraded or simplified ecosystems (Soulé et al. 2003, Ribes \& Coma 2005).

The importance of the delayed effects of mass mortality events, together with the potential increase in the frequency of these events, highlights the contribution of disturbance to the dynamics of Paramuricea clavata populations and to its role as a structuring force in the coralligenous community.

Acknowledgements. We are grateful to M. Ribes, J. Garrabou, and D. Doak for their valuable comments and critical evaluation of different versions of the manuscript. The comments of 2 anonymous reviewers contributed to improving the paper. We thank E. Ballesteros, L. de Maissonneuve, J. Garrabou, P. Lopez and M. Marí for their assistance in the field. Our work in Port-Cros was made easier by the staff of the Port-Cros National Park, and special thanks go to M. Tilman and P. Robert (the Port-Cros National Park manager). We thank the continuous encouragement and support J. D. Ros for over the years. Financial support for this work was provided by the Port-Cros National Park, the Total Foundation and by research grants REN2002-01631/MAR and CTM2004-03120/MAR from the 'Ministerio de Educación y Ciencia', Spain. This paper is dedicated to the memory of Lluís Dantart, who died in February 2005 in a car accident at the age of 42 . He was a great naturalist, an excellent photographer and overall a good friend. We miss you.

\section{LITERATURE CITED}

Aronson RB, Precht WF (1997) Stasis, biological disturbance, and community structure of a Holocene coral reef. Paleobiology 23:326-346

Baird AH, Marshall PA (2002) Mortality, growth and reproduction in scleractinian corals following bleaching on the Great Barrier Reef. Mar Ecol Prog Ser 237:133-141

Ballesteros E (in press) Mediterranean coralligenous assemblages: a synthesis of present knowledge. Oceanogr Mar Biol Annu Rev

Bavestrello G, Boero F (1986) Necrosi e rigenerazione in Eunicella cavolinii in Mar Ligure. Boll Mus Ist Biol Univ Genova 52:295-300

Bavestrello G, Bertone S, Cattaneo-Vietti R, Cerrano C, Gaino E, Zanzi D (1994) Mass mortality of Paramuricea clavata
(Anthozoa, Cnidaria) on Portofino Promontory cliffs, Ligurian Sea, Mediterranean Sea. Mar Life 4:15-19

Bethoux JP, Gentili B, Raunet J, Tailliez D (1998) Warming and freshwater budget change in the Mediterranean since the 1940s, their possible relation to the greenhouse effect. Geophys Res Lett 25:1023-1026

Cerrano C, Bavestrello G, Bianchi CN, Cattaneo-Vietti R and 8 others (2000) A catastrophic mass-mortality episode of gorgonians and other organisms in the Ligurian Sea (NW Mediterranean), summer 1999. Ecol Lett 3:284-293

Coma R, Ribes M (2003) Seasonal energetic constraints in Mediterranean benthic suspension feeders: effects at different levels of ecological organization. Oikos 101:205-215

Coma R, Ribes M, Gili JM, Zabala M (1998a) An energetic approach to the study of life-history traits of two modular colonial benthic invertebrates. Mar Ecol Prog Ser 161:89-103

Coma R, Ribes M, Zabala M, Gili JM (1998b) Growth in a modular colonial marine invertebrate. Estuar Coast Shelf Sci 47:459-470

Coma R, Ribes M, Gili JM, Zabala M (2000) Seasonality in coastal benthic ecosystems. Trends Ecol Evol 15:448-453

Coma R, Linares C, Pola E, Zabala M (2001) Seguiment temporal de la gorgònia Paramuricea clavata de les illes Medes. Exercici 2001. In: Zabala M (ed) Seguiment temporal de l'àrea marina protegida de les illes Medes. Informe anual any 2001. Departament de Medi ambient, Generalitat de Catalunya, Barcelona, p 59-82

Coma R, Linares C, Pola E (2003) Seguiment temporal de la gorgònia Paramuricea clavata de les illes Medes. Exercici 2003. In: Zabala M (ed) Seguiment temporal de l'àrea marina protegida de les illes Medes. Informe anual any 2003. Departament de Medi ambient, Generalitat de Catalunya, Barcelona, p 67-79

Coma R, Pola E, Ribes M, Zabala M (2004) Long-term assessment of the patterns of mortality of a temperate octocoral in protected and unprotected areas: a contribution to conservation and management needs. Ecol Appl 14:1466-1478

Epstein P, Sherman B, Spanger-Siegfried E, Langston A, Prasad S, McKay B (1998) Marine ecosystems: emerging diseases as indicators of change. Harvard Medical School, Cambridge, MA

Garrabou J, Harmelin JG (2002) A 20-year study on lifehistory traits of a harvested long-lived temperate coral in the NW Mediterranean: insights into conservation and management needs. J Anim Ecol 71:966-978

Garrabou J, Sala E, Arcas A, Zabala M (1998) The impact of diving on rocky sublittoral communities: a case study of a bryozoan population. Conserv Biol 12:302-312

Garrabou J, Perez T, Sartoretto S, Harmelin JG (2001) Mass mortality event in red coral Corallium rubrum populations in the Provence region (France, NW Mediterranean). Mar Ecol Prog Ser 217:263-272

Garrabou J, Ballesteros E, Zabala M (2002) Structure and dynamics of north-western Mediterranean rocky benthic communities along a depth gradient. Estuar Coast Shelf Sci 55:493-508

Greenstein BJ, Curran HA, Pandolfi JM (1998) Shifting ecological baselines and the demise of Acropora cervicornis in the western North Atlantic and Caribbean Province: a Pleistocene perspective. Coral Reefs 17:249-261

Guzmán HM, Cortés J (2001) Changes in reef community structure after fifteen years of natural disturbances in the eastern Pacific (Costa Rica). Bull Mar Sci 69:133-149

Harmelin JG (1984) Biologie du corail rouge. Paramètres de populations, croissance et mortalité. Etat des connaissances en France. In: Charbonnier D, Garcia S (eds) Rapport de consultation technique du CGPM sur les 
ressources du corail rouge de la Méditerranée occidentale et leur exploitation rationnelle. FAO rapport no. 306 sur les pêches, Palma de Mallorca, p 99-103

Harmelin JG (2004) Environnement thermique du benthos côtier de l'île de Port-Cros (parc national, France, Méditerranée nord-occidentale) et implications biogéographiques. Sci Rep Port-Cros Natl Park Fr 20:173-194

Harmelin JG, Marinopoulos J (1994) Population structure and partial mortality of the gorgonian Paramuricea clavata (Risso) in the north-western Mediterranean (France, PortCros Island). Mar Life 4:5-13

Harmelin JG, Sartoretto S, Francour P (1999) Mise en place d'une stratégie de suivi de l'ichtyofaune et des peuplements de gorgonaires de l'archipel de Riou. Contrat Ville de Marseille, Direction de l'environnement et des Déchets and Centre d'Océanologie de Marseille. Centre d'Océanologie de Marseille, Publ Marseille, p 1-110

Harvell CD, Mitchell CE, Ward JR, Altizer S, Dobson A, Ostfeld RS, Samuel MD (2002) Climate warming and disease risks for terrestrial and marine biota. Science 296: 2158-2162

Harvell C, Aronson R, Baron N, Connell J and 13 others (2004) The rising tide of ocean diseases: unresolved problems and research priorities. Front Ecol Environ 2:375-382

Hoegh-Guldberg O (1999) Climate change, coral bleaching and the future of the world's coral reefs. Mar Freshw Res 50:839-866

Hughes RN, Cancino JM (1985) An ecological overview of cloning in metazoa. In: Jackson JBC, Buss LW, Cook RE (eds) Population biology and evolution of clonal organisms. Yale Univ Press, New Haven, CT, p 153-186

Hughes TP (1994) Catastrophes, phase shifts, and large-scale degradation of a Caribbean coral reef. Science 265: $1547-1551$

Hughes TP, Jackson JBC (1985) Population dynamics and life histories of foliaceous corals. Ecol Monogr 55:141-166

Jackson JBC (1985) Distribution and ecology of clonal and aclonal benthic invertebrates. In: Jackson JBC, Buss LW, Cook RE (eds) Population biology and evolution of clonal organisms. Yale Univ Press, New Haven, CT, p 297-356

Jones CG, Lawton JH, Shachak M (1994) Organisms as ecosystem engineers. Oikos 69:373-386

Kim K, Harvell CD (2004) The rise and fall of a 6 year coralfungal epizootic. Am Nat 164:S52-S63

Laubier L (1966) Le coralligène des Albères. Monographie biocénotique. Ann Inst Océanogr Paris 43:139-316

Lewis JB (1997) Abundance, distribution and partial mortality of the massive coral Siderastrea siderea on degrading coral reefs at Barbados, West Indies. Mar Pollut Bull 34:622-627

Loya Y, Sakai K, Yamazato K, Nakano Y, Sambali H, van Woesik R (2001) Coral bleaching: the winners and the losers. Ecol Lett 4:122-131

Martin Y, Bonnefont JL, Chancerelle L (2002) Gorgonians mass mortality during the 1999 late summer in French Mediterranean coastal waters: the bacterial hypothesis. Water Res 36:779-782

McClanahan TR, Muthiga NA, Mangi S (2001) Coral and algal changes after the 1998 coral bleaching: interaction with reef management and herbivores on Kenyan reefs. Coral Reefs 19:380-391

Meesters EH, Wesseling I, Bak RPM (1996) Partial mortality in three species of reef-building corals and the relation with colony morphology. Bull Mar Sci 58:838-852

Mistri M, Ceccherelli VU (1996) Effects of a mucilage event on the Mediterranean gorgonian Paramuricea clavata. I. Short term impacts at the population and colony levels. Ital J Zool 63:221-230

Editorial responsibility: Roger Hughes (Contributing Editor), Bangor, UK
Monson DH, Doak DF, Ballachey BE, Johnson A, Bodkin L (2000) Long-term impacts of the Exxon Valdez oil spill on sea otters, assessed through age-dependent mortality patterns. Proc Natl Acad Sci USA 97:6562:6567

Morris WF, Doak DF (2002) Quantitative conservation biology: theory and practice of population viability analysis. Sinauer Associates, Sunderland, MA

Nagelkerken I, Buchan K, Smith GW, Bonair K and 10 others (1997) Widespread disease in Caribbean sea fans. II. Patterns of infection and tissue loss. Mar Ecol Prog Ser 160: $255-263$

Pascual J, Salat J, Palau M (1995) Evolución de la temperatura del mar entre 1973 y 1994, cerca de la costa catalana. In: Int Coll Okeanos, Montpellier p 23-28

Pearson RG (1981) Recovery and recolonization of coral reefs. Mar Ecol Prog Ser 4:105-122

Pérès JM, Picard J (1964) Nouveau manuel de bionomie benthique de la mer Méditerranée. Rec Trav Sta Mar Endoume 31:5-137

Perez T, Garrabou J, Sartoretto S, Harmelin JG, Francour P, Vacelet J (2000) Mortalité massive d'invertébrés marins: un événement sans précédent en Méditerranée nordoccidentale. CR Acad Sci Paris III 323:853-865

Ribes M, Coma R (2005) The role of engineer species in the benthic-pelagic coupling: the study case of a Mediterranean gorgonian. Am Soc Limnol Oceanogr Summer Meeting: 128

Ribes M, Coma R, Gili JM (1999) Heterogeneous feeding in benthic suspension feeders: the natural diet and grazing rate of the temperate gorgonian Paramuricea clavata (Cnidaria: Octocorallia) over a year cycle. Mar Ecol Prog Ser 183:125-137

Richardson LL (1998) Coral diseases: what is really known? Trends Ecol Evol 13:438-443

Rivoire G (1991) Mortalité du corail et des gorgones en profondeur au large des côtes provençales. In: Boudouresque

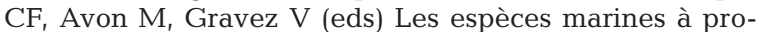
téger en Méditerranée. GIS Posidonie, France, p 53-59

Romano JC, Bensoussan N, Younes WAN, Arlhac D (2000) Anomalies thermiques dans les eaux du golfe de Marseille durant l'été 1999. Une explication partielle de la mortalité d'invertébrés fixés. CR Acad Sci Paris III 323: 415-427

Sebens KP (1991) Habitat structure and community dynamics in marine benthic systems. In: Bell SS, McCoy ED, Mushinsky HR (eds) Habitat structure. Chapman \& Hall, London, p 211-234

Soulé ME, Estes J, Berger J, Martinez del Rio C (2003) Ecological effectiveness: conservation goals of interactive species. Conserv Biol 17:1238-1250

True MA (1970) Étude quantitative de quatre peuplements sciaphiles sur substrat rocheux dans la région marseillaise. Bull Inst Oceanogr Monaco 1410:1-48

Underwood AJ (1994) On beyond BACI: sampling designs that might reliably detect environmental disturbances. Ecol Appl 4:3-15

Ward JR, Lafferty KD, Harvell CD (2004) The elusive baseline of marine disease: are diseases in ocean ecosystems increasing? PLoS Biol 2:542-547

Wendt PH, van Dolah RF, O'Rourke CB (1985) A comparative study of the invertebrate macrofauna associated with seven sponge and coral species collected from the South Atlantic Bight. J Elisha Mitchell Sci Soc 101:187-203

Wilkinson $\mathrm{C}$, Lindén $\mathrm{O}$, Cesar $\mathrm{H}$, Hodgson $\mathrm{G}$, Rubens $\mathrm{J}$, Strong AE (1999) Ecological and socioeconomic impacts of 1998 coral mortality in the Indian ocean: an ENSO impact and a warning of future changes? Ambio 28:188-196

Submitted: May 16, 2005; Accepted: July 13, 2005

Proofs received from author(s): November 10, 2005 